\title{
The Relationship of Smoking Habits, Cholesterol Level and Diabetes Mellitus (DM) History With Stroke Incidence in Patients at PKU Muhammadiyah Hospital Sruweng
}

\author{
Hendri Tamara Yuda ${ }^{1, *}$ Asri Munajah ${ }^{2}$ Podo Yuwono ${ }^{3}$
}

\author{
${ }^{1,3}$ Muhammadiyah Health Science Institute of Gombong \\ ${ }^{2}$ Muhamnmadiyah Hospital of Sruweng \\ *Corresponding author.Email: hendritamara@gmail.com
}

\begin{abstract}
Stroke is a health problem that attacks the neurological system. It may result in brain damage, paralysis and even death. Hypertension, smoking, Diabetes Mellitus, heart diseases, blood cholesterol levels, alcohol, and drug abuse are some of the risk factors that can be changed. The total outpatient stroke patients were 253 cases. This study is to determine the correlation of smoking habits, cholesterol levels and diabetes mellitus (DM) history with the incidence of stroke. This research is observational research. The samples were taken from 109 respondents using overall sampling technique. To determine the variable's correlation used Chi Square data analysis. Research resuls have a relationship between smoking habits, cholesterol levels, the history of diabetes mellitus with the incidence of stroke ( $p$ value $=0,000$ ) in patients at PKU Muhammadiyah Hospital Sruweng. There was a significant correlation between the variables (smoking habits, cholesterol levels and the history of diabetes mellitus) with the incidence of stroke in patients at PKU Muhammadiyah Hospital Sruweng
\end{abstract}

Keywords: Smoking, Cholesterol, DM, Stroke

\section{INTRODUCTION}

Strokes occur due to blood vessels that carry blood and oxygen to the brain determining blockages and ruptures, lack of oxygen causes control problems. [1]. According to [18], stroke is the third killer after heart disease and cancer. Moreover, it is in the first rank of disability in the world.

During the period of 2000-2016, 6 million people died from stroke according to a report from WHO [26]. In Europe, around 650,000 new cases of stroke are found each year. In the UK itself, stroke ranks the third as leading cause of dying after heart disease and cancer. In the United States, stroke is in the fourth rank causing death and main cause of disability in adults [17]. In Indonesia country, the incidence of stroke is also high and a major cause of death. Based on [20], the prevalence of stroke in Indonesia is 7.0 per mile based on the diagnosis of health worker.

Incidence rate of stroke in Central Java in 2016 was recorded as many as 3,472 cases (1.82\%) and this disease ranks the ninth non-communicable diseases [5]. The data reported from the Central Java Health Office [5] emphasized that the prevalence of hemorrhagic stroke in Central Java in 2012 was 0.07 higher than in 2011 of $(0.03 \%)$. In 2013, the number of stroke cases at the age of 15-44 years is as many as 1,118 cases ( 531 cases of non-hemorrhagic stroke and 587 cases of hemorrhagic stroke). In 2014, up to the second quarter the number of stroke cases at the age of 15-44 years in Central Java was 1,259 cases consisting of 687 nonhemorrhagic stroke cases and 572 hemorrhagic stroke cases (Central Java Provincial Health Office, 2014). Stroke risk factors can be categorized into two namely modified and cannot be changed (Smeltzer \& Bare, 2013). According to [14], age, gender, and ethnicity are irreversible risk factors for ischemic and hemorrhagic strokes, whilst hypertension, smoking, Diabetes Mellitus, heart disease, blood cholesterol levels, alcohol and drug abuse are some risk factors that can be changed.

The most modifiable risk factors for stroke as hypertension, heart disease and diabetes mellitus [14]. Diabetes mellitus is a risk factor for stroke that contributes to about $20 \%$ of deaths with a 2-fold increase in risk (Banerjee, 2012). The distribution of stroke in Dr. Moewardi Hospital Surakarta in 2010 was 66 stroke patients, with $71.21 \%$ of patients had a history of DM [19].

The relationship between cholesterol levels and stroke risk is characterized by an increase in total cholesterol, and a decrease in high-density lipoprotein (HDL) cholesterol [23]. However, the effect of triglycerides on stroke risk results is conflicting. The risk seems to depend on the stroke subtype, as in the finding that high cholesterol levels are more common in patients with large arterial ischemic stroke than other ischemic stroke subtypes eventhough there is a decrease in total cholesterol in patients with hemorrhagic stroke [8]. Meanwhile, smoking accounts for up to $15 \%$ of all deaths due to stroke per year [25]

Based on preliminary studies conducted in September 2018, in PKU Muhammadiyah Hospital Sruweng, stroke prevalence data were obtained between January and December 2017. There were 253 cases, and 52 cases had 
recurrent strokes. Meanwhile, in January to June 2018, there were 133 cases of stroke. In which the highest number of hemorrhagic stroke (HS) cases were in the ICU, and the highest number of non-hemorrhagic strokes (NHS) were treated in Ahmad Dahlan's room. The researchers also interviewed 10 patients treated. The result show that there were 7 male patients, and 8 patients were over 55 years, 2 patients have heart disease history, 1 patient has DM history and all patients have hypertension history. Some of them have more than 1 factor, such as 3 people who smoke have a history of hypertension and high cholesterol. There are also those who have both high cholesterol levels DM history. This study is to determine the correlation of smoking habits, cholesterol levels and diabetes mellitus (DM) history with the incidence of stroke.

\section{RESEARCH METHOD}

This research used observational research. This study applied a cross sectional design, namely the causes and effects that occur in the object of research measured or collected simultaneously and at the same time

The population of this study was all stroke patients undergoing inpatient care and outpatient care at $P K U$ Muhammadiyah Hospital Sruweng Hospital from April June 2018, as many as 109 patients. The sampling method in this study used total sampling, having 109 respondents were found. Primary data collection method was obtained from patients who came with stroke, in outpatient and inpatient care, while the secondary data used questionnaire sheets. The study was conducted at PKU Muhammadiyah Hospital Sruweng in November 2018 to January 2019.

The data analysis in this study used the chi-square test to find out the significant relationship between each independent variable with the dependent variable. The basis for decision making in accepting the research hypothesis based on the level of significance ( $p$ value) is $<0.05$.

\section{RESEARCH RESULT}

\subsection{Smoking habit}

Based on the results from the table, it was describe that the number of respondents who have blood cholesterol levels $\geq 200 \mathrm{mg} / \mathrm{dl}$ are the majority of respondents on nonhemorrhagic stroke $(53.2 \%)$. Then, the respondents with cholesterol levels $<200 \mathrm{mg} / \mathrm{dl}$, were the largest proportion of respondents with hemorrhagic strokes as many as $30.3 \%$ and the lowest in non-hemorrhagic strokes has a value of $13.8 \%$. The results of statistical obtain $p=0,000$. Hence, conclusion can be drawn that cholesterol levels are associated with stroke incidence.
Table 1. The Relationship between smoking habits and stroke incidence at PKU Muhammadiyah Hospital Sruweng $(n=109)$.

\begin{tabular}{ccccccccc}
\hline Smoker & \multicolumn{5}{c}{ Stroke incidence } & \multicolumn{2}{c}{ Total } & P value \\
\cline { 2 - 5 } & SH & \multicolumn{3}{c}{ SNH } & & & \\
\cline { 2 - 6 } & $\mathrm{N}$ & $\%$ & $\mathrm{~N}$ & $\%$ & $\mathrm{~N}$ & $\%$ & \\
\hline No & 5 & 4,6 & 46 & 42,2 & 51 & 46,8 & 0,000 \\
Yes & 31 & 28,4 & 27 & 24,8 & 58 & 53,2 & \\
\hline Total & 36 & 33 & 73 & 67 & 109 & 100 & \\
\hline
\end{tabular}

Source: Primary Data (2019)

Based on the results from the table, it was describe that the number of respondents who smoked mostly suffered from hemorrhagic strokes, with the number of $28.4 \%$ and the lowest in non-hemorrhagic strokes was $24.8 \%$. Then, the respondents who did not smoke showed that the highest number of proportions in non-hemorrhagic stroke was $42.2 \%$ and the lowest in hemorrhagic stroke was $4.6 \%$. The results of statistical obtainable $\mathrm{p}=0,000$. Thus, conclusion can be drawn that smoking is related to the incidence of stroke.

\subsection{Blood Cholesterol Level}

Table 2: The Correlation between Blood Cholesterol Level and Stroke incidence in PKU Muhammadiyah Hospital Sruweng $(n=109)$.

\begin{tabular}{|c|c|c|c|c|c|}
\hline Level & & Strol & incidence & Total & value $p$ \\
\hline Cholesterol & HS & & NHS & & \\
\hline Blood & $\mathrm{N}$ & $\%$ & $\mathrm{~N}$ & $\mathrm{~N}$ & \\
\hline
\end{tabular}

\begin{tabular}{cccccccc}
\hline$<200 \mathrm{mg} / \mathrm{dl}$ & 33 & 30,3 & 15 & 13,8 & 48 & 44 & 0,000 \\
$\geq 200 \mathrm{mg} / \mathrm{dl}$ & 3 & 2,8 & 58 & 53,2 & 61 & 56 & \\
\hline Total & 36 & 33,1 & 73 & 67 & 109 & 100 \\
\hline \multicolumn{7}{c}{ Source: Primary Data (2019) }
\end{tabular}

\subsection{History of Diabetes Mellitus}

Table 3. The Relationship between Diabetes Mellitus and Stroke Incidence at PKU Muhammadiyah Hospital Sruweng $(n=109)$.

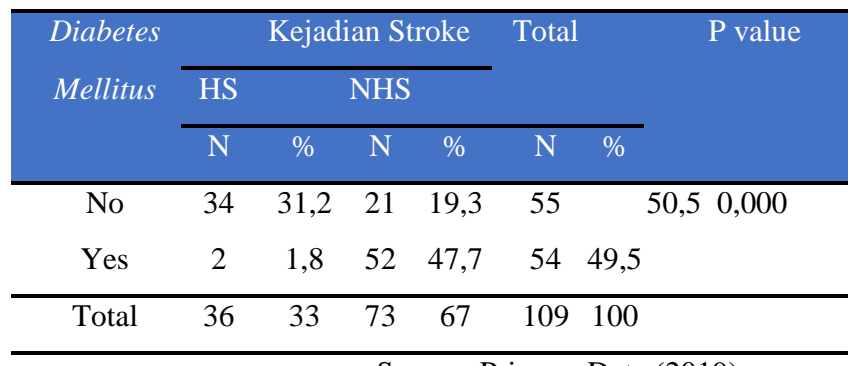

Source: Primary Data (2019) 
The analysis showed that the majority of respondents had a history of diabetes mellitus, in which the majority of respondents in non-hemorrhagic strokes was $47.7 \%$, and had hemorrhagic strokes with a proportion of $1.8 \%$. Furthermore, for respondents with no history of diabetes mellitus, the majority of respondents had hemorrhagic strokes with a presentation of $31.2 \%$ and the least was non-hemorrhagic strokes with a percentage of $19.3 \%$. The results of statistical obtainable $\mathrm{p}=0,000$. Therefore, as a conclusion, the history of diabetes mellitus influence the incidence of stroke.

\subsection{Overview of stroke rates}

The data description of the incidence rate of stroke in PKU Muhammadiyah Sruweng Hospital is grouped into two categories, namely hemorrhagic stroke (HS) and nonhemorrhagic stroke (NHS). The stroke frequency distribution can be seen in the following table.

Table 4. Frequency Distribution, Stroke Rate at $P K U$ Muhammadiyah Hospital Sruweng in 2018-2019 ( $\mathrm{n}=109)$.

\begin{tabular}{ccc}
\hline Stroke rate & Frequency & Percentage (\%) \\
\hline Hemorrhagic Stroke (SH) & 36 & 33 \\
Non-Hemorrhagic Stroke (NHS) & 73 & 67 \\
\hline Total & 109 & 100,00
\end{tabular}

Based on the Table 4, it can be seen that the majority of respondents suffered non-hemorrhagic strokes which is 73 people $(67 \%)$, and the fewest number of respondents with hemorrhagic strokes were 36 people (33\%).

\section{DISCUSSION}

\subsection{Smoking as a risk factor for stroke rate}

Based on Table 1, the numbers of respondents who smoked are more than those who did not smoke. Respondents who smoked mostly suffered hemorrhagic strokes, with the number of $28.4 \%$ and the lowest in nonhemorrhagic strokes, amounting to $24.8 \%$. Then, among the respondents who did not smoke, it is found that the highest number of proportions in non-hemorrhagic strokes, amounted to $42.2 \%$ and the lowest in hemorrhagic strokes by $4.6 \%$. Meanwhile, The results of statistical obtainable $\mathrm{p}=$ 0,000 , conclusion can be drawn that there is an influence of smoking risk factors with the incidence of stroke. This is consistent with [12] which states that male smokers have a risk of having a stroke hemorrhage that is 2.36 times greater than those hemorrhagic stroke with intra cerebral hemorrhage is mostly occurs due to most often occurs due to vascular injury triggered by hypertension, and rupture which one of many small arteries that penetrate deep into brain tissue [9].

According to the analysis nicotine contained in cigarettes will will narrow the blood vessels resulting in increased blood pressure, while the large number of cigarettes, and long smoking, is a cause of increased high blood pressure. In this study, the active smokers suffering stroke had a smoking habit. They spent about> 20 cigarettes per day and an average smoking duration of $>10$ years. The respondents also often experience high blood pressure and headaches. [7] states that the effect of nicotine causes an increase in blood pressure, pulse, and blood flow so that it can cause rupture of blood vessels in the brain (aneurysm). Aneurysm is what causes hemorrhagic strokes. A research conducted by [15] shows that the number of cigarettes smoked per day has a significant relationship with the incidence of stroke, patients who smoke> 20 cigarettes per day (heavy smokers) have a risk of stroke, and the length of smoking also has a significant relationship with the incidence of stroke.

\subsection{Blood Cholesterol Levels as Risk Factors for Stroke incidence.}

The results showed that the number of respondents who had blood cholesterol levels $\geq 200 \mathrm{mg} / \mathrm{dl}$ Among the respondents with stroke. The majority were nonhemorrhagic strokes $(53.2 \%)$, while the lowest was respondents with a number of $56 \%$ and the smallest number was in hemorrhagic strokes by $2,8 \%$. Then among respondents with a value $<200 \mathrm{mg} / \mathrm{dl}$, the largest proportion of respondents with hemorrhagic strokes as much as $30.3 \%$ and the lowest in non-hemorrhagic strokes with a value of $13.8 \%$. The results of statistical obtainable $p=0,000$. Therefore, conclusion can be drawn that blood cholesterol levels affect the incidence of stroke.

[2] showed that there were differences in total cholesterol level, between patients with ischemic stroke and hemorrhagic stroke. The total cholesterol level in ischemic stroke patients was higher than hemorrhagic stroke sufferers with a significance value of $\mathrm{p}=0.005(\mathrm{p}<0.05)$. The results of this study are consistent with the research conducted by $[4,11,13]$ suggesting that there are significant differences in total cholesterol level between ischemic and hemorrhagic stroke sufferers, where sufferers of ischemic stroke have higher total cholesterol level than hemorrhagic stroke sufferers.

High total cholesterol level is one of the modifiable risk factors, which can cause ischemic stroke (Wang et al, 2013). High total cholesterol levels can cause atherosclerosis, which is the basic pathology in the occurrence of ischemic stroke [13]. High total cholesterol level can be found in $19 \%$ of total ischemic stroke sufferers, and has been proven as an independent predictor for ischemic stroke sufferers. Low total cholesterol level was associated with micro aneurysms which can cause intra cerebral hemorrhage (ICH).

At the time of the interview, the majority of respondents had unhealthy eating patterns, such as excessive consumption of offal, and eating fried foods, while eating less fibrous vegetables. The tendency of the respondents is not obesity but having high cholesterol levels. In fact many respondents who do not believe if they have high cholesterol, while the body is normal and even thin. According to [6], excessive cholesterol will not be stored under the skin but in the blood. 
The excess cholesterol will be accumulated in the blood vessels and plaque will occur. The presence of plaque will create stiffness and blockage in blood vessels so that it triggers a stroke. [10] in his research on dyslipidemia, found that more than $50 \%$ of samples have high cholesterol level in which the high cholesterol level is a significant.

\subsection{Diabetes Mellitus as a Risk Factor for Stroke incidence}

The analysis showed that the majority of respondents had a history of diabetes mellitus, where finding the majority of respondents in non-hemorrhagic strokes were $47.7 \%$, and the least hemorrhagic strokes with a proportion of $1.8 \%$. Furthermore, for respondents with no history of diabetes mellitus, the majority of respondents had hemorrhagic strokes with a presentation of $31.2 \%$ and the least were nonhemorrhagic strokes with a percentage of $19.3 \%$. The results of statistical obtainable $\mathrm{p}=0,000$, so conclusion can be drawn that Diabetes Mellitus factors affect stroke incidence.

In the study of O'Donnell et al (2010) an OR value of 1.60 (CI 99\%: 1.29-1.99) states that people who have Diabetes Mellitus have a 1.6 times greater risk of suffering from ischemic stroke than people who don't suffer from Diabetes Mellitus. In addition to the presence or absence of diabetes, the incidence of both ischemic and hemorrhagic strokes is also influenced by the duration of a person suffering from Diabetes Mellitus. [3] stated that each year,the patients having diabetes will the risk of suffering from ischemic stroke by $3 \%$, It also emphasized that the length of a person suffering from Diabetes Mellitus has a significant correlation with the with the incidence of ischemic stroke.

In this study, the respondents with diabetes often ignore healthy lifestyles, such as rarely consuming fruits and vegetables and exercising but often exercising, but often consuming foods that contain lots of salt, and oil as snacks. In addition, patients also rarely come to the health center, The elderly also seldom visiting the health center to check the blood pressure and monitor the sugar level. Thus, the researchers assume that excessive and uncontrolled blood sugar can cause blockages in blood vessels, including blood vessels in the brain. This is in line with the research by [21] proving that the cause of diabetes mellitus and ischemic stroke is the existence of a process of atherosclerosis. About $30 \%$ of patients with cerebral atherosclerosis are proven to have diabetes. Macroangiopathy process is considered highly relevant to stroke, which is characterized by the occurrence of lacunars stroke in patients with Diabetes Mellitus.

\section{CONCLUSION}

It is proven that smoking habits, cholesterol levels, and the history of diabetes mellitus have significant correlation with the incidence of stroke in patients at $P K U$ Muhammadiyah Hospital Sruweng.

\section{REFFERENCES}

[1] American Heart Association (AHA). (2015). Heart Disease and Stroke Statistics - At-a-Glance [Artikel]. Accessed on 14 September 2018

[2] Aini, A.Q., Pujarini,L.A., \& Nirlawati,D.D. (2016). Perbedaan Kadar Kolesterol Total Antara Penderita Stroke Iskemik Dan Stroke Hemoragik. Biomedika, Volume 8 Number 2, Agustus 2016

[3] Banerjee, Chirantan, dkk. (2012). Duration of Diabetes and Risk of Ischemic Stroke. New York: Mailman School of Public Health, Columbia University

[4] Chaudhury, S.R., Ghosh,S., Kar,D. (2010). Comparative Lipid Profile Study Between Ischemic and Hemorrhagic Stroke. J. Chem.Pharm. Res. 6(11): 20-7

[5] Dinkes Jawa Tengah.(2016). Buku Saku Kesehatan Tahun 2016.Semarang: Dinkes Province of Central Java

[6] Gofir, A. (2009). Manajemen STROKE. Yogyakarta: Pustaka cendekia press

[7] Guyton, A. C., Hall, J. E. (2014). Buku Ajar Fisiologi Kedokteran. Edisi 12. Jakarta : EGC, 1022

[8] Iribarren, C., Jacobs, D.R., Sadler, M., Claxton, A.J., Sidney, S. (2006). Low total serum cholesterol and intracerebral hemorrhagic stroke: is the association confined to elderly men? The Kaiser Permanente Medical Care Program. Stroke. 27:1993-1998

[9] Hartwig, M.J. (2006). „Penyakit Serebrovaskular'. Jakarta:EGC

[10] Kamso, S., Oemardi,M., et al. (2012). Metabolic syndrome in the elderly should it be. Eng J Med:346

[11] Khan, M. G. (2006). Encyclopedia of Heart Disease. UK: Elsevier Academic Press

[12] Kurth T, Kase CS, Berger K, Schaeffner ES, Buring JE, Gaziano JM. (2013). Smoking and the risk of hemorrhagic stroke in men. Stroke. 34:1151-1155

[13] Mahmood A., Sharif M.A., Khan M.N., Ali U.Z. (2010). Comparison of Serum Lipid Profile in Ischaemic and Haemorrhagic Stroke. JCPSP. 20(5):317-20

[14] Mansjoer, A. (2016). Kapita Selekta Kedokteran. Edisi 4. Jilid 2. Medika Auskulapius FKUI: Jakarta

[15] Marisa.(2012). Hubungan Perilaku Merokok Dengan Kejadian Stroke Di Bagian Saraf RSU Dokter Soedarso Pontianak Periode Juni-Juli 2012

[16] O'Donnell, M.J., Xavier, D., Liu, L., et al.; INTERSTROKE investigators. (2010). Risk factors for ischaemic and intracerebral haemorrhagic stroke in 22 countries (the INTERSTROKE study): a case-control study. Lancet. 376:112-123. doi: 10.1016/S01406736(10)60834-3

[17] Palermo, E. (2014). Stroke: Symptoms, Tests and Treatment [Internet]. Accesed on 11 September 2018

[18] Pinzon. (2010). Awas stroke! Pengertian, gejala, tindakan, perawatan, dan pencegahan. Yogyakarta. Cv Andi Offset 
[19] Ramadany, A.F., Pujarini, L.A \& Candrasari,A. (2013). Hubungan Diabetes Melitus Dengan Kejadian Stroke Iskemik Di RSUD Dr. Moewardi Surakarta Tahun 2010. Biomedika Journal, Volume 5 Number 2, Agustus 2013. Surakarta: Universitas Muhammadiyah Surakarta

[20] Riset Kesehatan Dasar. (2013). Angka Kejadian Stroke Menurut Riskesdas. Accesed from: http://www.riskesdas.litbang.depkes.go. id/ date 6 September 2018

[21] Ryden, L., Standl, E., Bartnik, M. et al., (2007). Guideline on Diabetes, rediabetes, and cardiovaskuler disease. Eropean Heart Journal Supplement
[22] Smeltzer \& Bare. (2013). Buku Ajar Keperawatan Medikal Bedah Brunner dan Suddarth (Ed.8, Vol. 1,2). Jakarta : EGC

[23] Soyama,Y., Miura, K., Morikawa,Y., Nishijo, M., Nakanishi,Y Naruse. (2013). High-density lipoprotein cholesterol and risk of stroke in Japanese men and women: The Oyabe Study. Stroke. 34:863868. doi: 10.1161/01.STR.0000060869.34009.38

[24] Wang,X., Dong,Y., Qi,X., Huang, C., Hou,L. (2013). Cholesterol Levels and Risk of Hemorrhagic Stroke. Stroke. 10:1833-9

[25] Thun,M.J., Apicella, L.F., Henley,S.J. (2012). Smoking vs other risk factors as the cause of smokingattributable deaths: confounding in the courtroom. JAMA. 284:706-712

[26] WHO. (2018). The top 10 causes of death. Accesed on 2 November 2018 